\title{
Determinants of Banks' Capital Structure: Evidence from Vietnamese Commercial Banks
}

\author{
Tong Trung Tin, MBA \\ Dept. of Business, Chung Yuan Christian University \\ No. 200, Zhongbei Road, Zhongli District, Taoyuan City, Taiwan \\ Tel: 886-0938650687_E-mail: trungtintong@gmail.com \\ John Francis T. Diaz, Associate Professor \\ Dept. of Finance, Chung Yuan Christian University \\ No. 200, Zhongbei Road, Zhongli District, Taoyuan City, Taiwan \\ Tel: 886-(03)265-5708_E-mail: johnfrancis_diaz@yahoo.com
}

Received: April 2, 2017 Accepted: April 29, $2017 \quad$ Published: June 1, 2017

doi:10.5296/ajfa.v9i1.11150 URL: http://dx.doi.org/10.5296/ajfa.v9i1.11150

\begin{abstract}
This paper investigates the important factors influencing capital structure decisions. The study focuses on the bank leverage of thirty-one Vietnamese commercial banks from 2009 to 2014, because they play a key role as financial catalysts in the growing economy of Vietnam. The analysis employs multiple linear panel regression models, namely, Ordinary Least Squares (OLS), Fixed Effects (FE), and Random Effects (RE). This research examines five bank-specific factors (i.e., size, profitability, growth rate, taxation and business risk), and three financial market and economic variables (i.e., stock market condition, economy, and inflation) influencing capital structure with debt ratio as the dependent variable. Both the OLS and FE models agree that a Vietnamese bank's size positively affects leverage, which means that the larger the bank, the more debt is incurred. Both models also determine that stock market and economic conditions have negative effects, which implies that in good market conditions, banks lessen their debt loads. In dividing Vietnamese commercial banks into three groups of sizes (i.e., large, medium-sized and small banks) based on chartered capital, both the OLS and RE models agree that size is a positively contributing factor to leverage. However, unlike large Vietnamese banks, medium-sized and small-sized banks tend to still carry a relatively high amount of debt because they are commonly ignored by the
\end{abstract}




\section{Macrothink}

Asian Journal of Finance \& Accounting ISSN 1946-052X 2017, Vol. 9, No. 1

equity markets for reasons of illiquidity and instability, pushing them to rely on borrowing funds even to the point of having higher interest rates. Another interesting finding of this paper is that, only small-sized Vietnamese banks' leverage is negatively affected by stock market and economic conditions. Findings of this paper are robust in using two panel regression models, and can help Vietnamese banks' managers have a general perspective regarding capital structure determinants. This study also offers insights in creating appropriate strategies to controlling factors affecting banks' leverage to achieve the target capital structure that minimizes the cost of capital and maximizes profitability.

Keywords: Capital structure determinants, Vietnamese commercial banks, Ordinary least squares, Fixed effect model, Random effect model 


\section{Introduction}

Growing optimism has emerged both in the world economy, especially the banking industry as recovery continues to get stronger from the impact of the Subprime Mortgage crisis. The recent financial crisis, which started December 2007 to June 2009 is considered to be the worst crisis for banking industry all over the world, widely believed to be caused by banks' excessive leverage. Different from other industries, banks always have a very high leverage compared with other non-financial firms (Osterberg \& Thompson, 1990) because most banks' profits come from liabilities in the form of interest-bearing deposits that must be managed properly to maximize profits. Banks have to ensure covering the risk of bankruptcy and hold more capital than required by regulations.

Factors affecting capital structure of financial institutions in the world have attracted numerous empirical studies highlighting the importance of properly managing a bank's capital structure. In particular, Juca et al. (2012) tested the influence of standard determinants of capital structure on the North American financial institutions under the effect of Basel agreements. The study confirmed that the hypothesis holds, and among the significant determinants are asset risks, amount of deposits, profitability and growth opportunities. Earlier studies conducted by Octavia and Brown (2010), and Gropp and Heider (2010) indicated that commercial banks with higher capital owned than the Basel minimum requirement have lesser risk. The studies also found that company-specific factors like size, profitability, growth opportunity, bank guarantees ${ }^{1}$, dividend payment and assets risk, and as well as macroeconomic fundamental variables like GDP growth and market return all have positive significant effect on the capital structure. Study on Asia's determinants of banking capital structure has also caught the attention of Hoa and Kayani (2013). The research found that economic growth stage of the countries under study determines the disparity in capital structure. Moreover, findings showed that collateral is the only significant factor in Asian developed countries, whereas profit is a significant factor in developing countries.

Vietnam is one of Asia's fastest growing economies has become a major player in global finance. Although, Vietnam's organized banking industry has a short history of about three decades, it has reformed and accomplished remarkable changes in terms of structure, regulation, and operations of banks. These developments have moved the banking sector towards a fast-growing operation that closely resembles domestic banking sectors in other emerging markets and newly industrialized economies.

Vietnam's economy is considered to be a market economy that uses ideologies of the capitalist system, but also maintains control of the government. Most of Vietnamese enterprises are small- and medium-scale enterprises, and most of them were owned and controlled by the government. However, since the Economic Reform was implemented in 1986, private partnerships reduced a large number of state-owned enterprises and encouraged the equalization of private firms, established joint-stock companies, as well as boosted the development of Vietnamese stock market. Although government plays less important role in

\footnotetext{
${ }^{1}$ Bank guarantee is defined as a promise from a bank that the liabilities of a debtor will be met in the event that a client fails to fulfill its contractual obligations.
} 
controlling enterprises, Okuda and Nhung (2012) still found a strong positive relationship between state-owned enterprises and company leverage. As a result, state-controlled companies tend to have higher debt ratio because they have more access to capital and can easily borrow money from state-controlled banks compared with non-state-owned companies. Dung (2015) found that among industries in Vietnam, Construction, Construction materials, Real estate, and Mining have the top highest leverage, followed by Manufacturing, Steel and Plastics, and Packaging. On the other hand, Anh (2010) examined capital structure determinants of companies listed in the Ho Chi Minh Stock Exchange. The study showed that the average debt ratio in the period of $2007-2009$ is about $51.74 \%$, however, there is a big disparity between industries, from $3.26 \%$ to $92.98 \%$.

For some Vietnamese industry specific findings on capital structure, Thu (2012) investigated capital structure determinants of listed real estate company. The findings showed that average leverage ratio of Vietnam's real estate industry is $54.93 \%$; and the leverage which is contributed by short-term debt is $64.97 \%$. This study also suggested four main explanatory determinants which are firm size, growth rate, profitability and cost of goods sold ratio. An earlier study of Canh and Cuong (2011) assessed the factors affecting the capital structure of Vietnam's seafood processing enterprises in comparison with enterprises of other processing industries. The results show that Vietnam's seafood industry has debt ratio of $60.3 \%$ and significant determinants include profitability, growth, agency cost and interest expense.

This research is motivated by the lack of empirical literature in determining the factors that affect the capital structure of Vietnam's banking industry with particular focus on bank leverage. This paper plans to augment empirical findings on the banking industry of Vietnam. This paper contributes to the literature by studying the determinants affecting the capital structure of Vietnam's banking industry using Ordinary Least Squares (OLS) model, Fixed Effect (FE) model, and Random Effect (RE) model. The study will also try to improve contributions by attempting to divide the samples into three major categories based on chartered capital: a) large capitalization banks ( 8 banks with chartered capital greater than USD 468 million or VND 10 trillion), b) medium capitalization banks (11 banks with chartered capital from USD 234 million to USD 468 million or VND 5 trillion to VND 10 trillion), and c) small capitalization banks (12 banks with chartered capital less than USD 234 million or VND 5 trillion).

The general objective of this research is to identify significant determinants of capital structure in Vietnam's banking industry; and the three specific objectives are:

- to examine the degree of relationship (i.e., positive or negative relationship) between bank leverage and selected internal and external factors;

- to identify which determinants from firm-specific to economic factors have stronger influence based on the coefficients' outcome; and

- to determine if there are differences on the significant factors determining the capital structure of large, medium and small capitalization banks.

The study's objectives are of significant interest, because identifying factors influencing 


\section{Ml Macrothink}

Asian Journal of Finance \& Accounting

ISSN 1946-052X

2017, Vol. 9, No. 1

Vietnamese banks' capital structure can provide insights to bank decision-makers and corporate research divisions. Given the paper's future findings, responsible parties inside the bank are able to monitor and even control relevant firm-specific and macroeconomic factors to create timely and beneficial financial decisions.

The paper is structured as follows: Section 1 introduced the background of global banking capital structure and Vietnam banking industry in general. Section 2 defines the independent variables and their expected relationship to the capital structure. Section 3 presents the data and explains the methodologies of the paper. Section 4 discusses the empirical results in detail, and Section 5 concludes and provides the limitations of the paper.

\section{Variables Definition and Hypotheses}

The relationships of independent variables to the degree of leverage, which corresponds to the percentage of total liabilities to the total assets of Vietnamese commercial banks, as well as hypotheses are summarized in Table 1. Below are the definitions and hypotheses for dependent and independent variables:

Table 1. Variables definition and measurement

\begin{tabular}{|l|c|c|l|l|}
\hline \multicolumn{1}{|c|}{ Variables } & Abbreviation & Relationship & \multicolumn{1}{|c|}{ Description } & \multicolumn{1}{|c|}{ Formula } \\
\hline $\begin{array}{l}\text { Linancial } \\
\text { Size }\end{array}$ & LEV & $\begin{array}{c}\text { Dependent } \\
\text { variable }\end{array}$ & $\begin{array}{l}\text { Correspond to the percentage of } \\
\text { bank's liability }\end{array}$ & $\begin{array}{l}\text { Total Liabilities / } \\
\text { Total Assets }\end{array}$ \\
\hline Profitability & SROF & $(+)$ & $\begin{array}{l}\text { Correspond to the natural } \\
\text { logarithm of the total assets }\end{array}$ & Ln (Total Assets) \\
\hline $\begin{array}{l}\text { Growth } \\
\text { Opportunity }\end{array}$ & GROW & $(+)$ & $\begin{array}{l}\text { Correspond to the bank's } \\
\text { profitability percentage }\end{array}$ & $\begin{array}{l}\text { EBIT / Total } \\
\text { Assets }\end{array}$ \\
\hline Tax Rates & TAX & $(+)$ & $\begin{array}{l}\text { Correspond to the percentage of } \\
\text { tax payment over EBIT }\end{array}$ & Tax Paid / EBIT \\
\hline Business Risk & RISK & $(-)$ & $\begin{array}{l}\text { Correspond to the probability of } \\
\text { financial distress }\end{array}$ & $\begin{array}{l}\text { Standard deviation } \\
\text { of EBIT }\end{array}$ \\
\hline $\begin{array}{l}\text { Stock Market } \\
\text { Condition }\end{array}$ & STK & $(-)$ & $\begin{array}{l}\text { Correspond to the stock market } \\
\text { index at respective time }\end{array}$ & $\begin{array}{l}\text { Vietnam stock } \\
\text { market index }\end{array}$ \\
\hline $\begin{array}{l}\text { Economic } \\
\text { Condition }\end{array}$ & ECON & $(-)$ & $\begin{array}{l}\text { Correspond to the percentage of } \\
\text { annual growth of Gross } \\
\text { Domestic Product (GDP) }\end{array}$ & $\begin{array}{l}\text { Annual } \\
\text { percentage change } \\
\text { of Vietnam's GDP }\end{array}$ \\
\hline Inflation & INF & $(+)$ & $\begin{array}{l}\text { Correspond to the percentage of } \\
\text { annual growth of Consumer } \\
\text { Price Index (CPI) }\end{array}$ & $\begin{array}{l}\text { Annual } \\
\text { percentage change } \\
\text { of Vietnam's CPI }\end{array}$ \\
\hline
\end{tabular}

Description: Variable definitions and summary of related hypotheses

Source: Organized by authors

Financial leverage is measured as the percentage of debt which firms utilize to acquire additional assets. According to the research of Rajan and Zingales (1995), they suggested 
four alternative definitions for financial leverage, namely: ratio of total liabilities to total assets, ratio of debt to total assets, ratio of total debt to net assets, and ratio of EBIT to interest expense. Among these definitions, ratio of total liabilities to total assets is considered to be the broadest one, it can be viewed as a better proxy for what is left for shareholders in case of liquidation. Also, this definition is supported by study of Ali et al. (2011). For these reasons, this paper uses ratio of total liabilities to total assets as an indicator for financial leverage, and the primary dependent variable of the study.

Size is measured in terms of total assets. From this definition, we can conclude that the more assets a firm owns, the bigger its size is. According to the Bankruptcy cost theory, firms with large size tend to borrow more debts than small ones, because of having easier access to capital markets (i.e., high credit rating and good reputation), as well as good relationship with creditors (Vatavu, 2012). This claim was also supported by the study of Strebulaev and Kurshev (2006) and found that a firm with bigger size has positive relationship with leverage, and more often offered with low interest rate. Hence, from these previous studies, this paper hypothesizes that size and leverage are positively related.

Profitability directly measures the performance of firms, and is defined as the money that company makes after accounting for all the expenses and taxes. Thus, this paper considers the value of a bank's net income to measure profitability. Conclusions on the relationship of profitability and leverage are mixed. Based on the Agency cost theory, Jensen (1986), and Williamson (1988) stated that profitable firms usually have higher free cash flow which encourages managers to invest discretionally. To restrain this agency problem, debt is chosen as an effective tool for managers to be more disciplined in continuing profitability in order to service debt. Thus, we can say that high profitable firms are absorbing more debt, making them positively related. On the contrary, Aremu et al. (2013) used the Pecking order theory to explain that profitable firms prefers internal financing. Thus, profitable firms tend to retain more profit for expansion instead of servicing debts, which makes the relationship negatively related. For this paper, we will be taking the standpoint of the Pecking order theory and will assume that profitability and debt have inverse relation.

Growth rates measures the potential of firms to expand their business in the future or the investment opportunities that a firm can foresee. In this paper, growth rate is measured using the market value of the firm over the book value of its total assets. Based on the explanation of Chen and Zhao (2006) using the Pecking order theory, they suggested that when firms see good opportunities in the future, they demand more capital for investment, and firms prefer debt over the issuance of stock; thus, making the relationship of growth and leverage positive. However, Barclay et al. (2006), and Pandey (2001) both explained through the Agency cost theory that when firms have positive future prospects, they don't want creditors to put pressure on corporate decisions as part of the conditions to the money being loaned, that's why they lower the level of debt. Another explanation was given earlier by Myers (1977), assuming that growth opportunities may take risk, and managers don't want to take more risky positions by incurring a higher level of debt. As the result, firms prefer internal capital sources instead of acquiring debt making the relationship negative. For the purposes of this paper, we will be taking again the position of the Pecking order theory and will assume that 
growth rate and leverage have positive relation.

Tax rates are compulsory contribution levied by the local government are applied to all of the firms and also play an important role in capital structure decision. Firms with high degree of leverage can get much benefit from tax shield, because interest on debt is a tax-deductible expense. Trade-off theory explains that in case of higher tax rate, firms will issue more debt to obtain a tax shield gain (Modigliani \& Miller, 1963); and the study of MacKinlay (2013) provided evidence that the marginal tax rate affect financing decision. However, study of Vatavu (2012) showed evidences that tax rate is not a significant factor with leverage. For the purposes of this study, we hypothesize that tax rates are positively related with leverage, because of the influence of tax shields.

Business risk is the possibility of inadequate profits or even losses due to market uncertainties like changes in preferences of customers, employee strikes, increase competition, obsolescence and even changes in government policy, which immediately affects earnings before interest and taxes (EBIT). The effect of risk on leverage is explained by the Bankruptcy cost theory. An earlier study of Titman and Wessels (1988) explained that less stable earnings firms bear higher bankruptcy cost; thus, they refuse to add more debt. Moreover, Agency cost theory confirms that when facing bankruptcy risk, agency problems related to debt are worse (Aremu et al., 2013). However, according to Vatavu (2012), contrary with most of other studies, he said that firms continue to use debt even when they face high business risk, because of trying to maximize the benefits that come from leverage. For this paper, we will be taking the standpoint of the Bankruptcy cost theory and will assume that business risk is negatively related with incurring more debt.

Stock market conditions refers to returns on the stock prices using a stock index, which affects the overall market valuation of firms. The relationship between stock market condition and leverage is explained by the Market timing theory. Frank and Goyal (2009), and Welch (2004) showed that firms issue equity (less of debt) when their market valuations are high, which negatively affects leverage.

Economic condition is general state of the economy, and will be measured by the annual percentage of Vietnam's GDP. In boom economy, most firms' profit goes up and firms will prefer internal sources like retained earnings over debt during expansions according to the Pecking order theory, and this was confirmed by the empirical studies of Dincergok and Yalciner (2011), stating the negative relationship between economic conditions and the level of debt. However, an earlier study of Gertler and Gilchrist (1993) showed that during good economic conditions, stock prices go up, bankruptcy cost declines, taxable income increases, and cash rises; and these factors encourage firms to borrow more making the relationship positive. For the purposes of this paper, we will be taking again the position of the Pecking order theory and will assume that economic condition and leverage has negative relation.

Inflation directly affects the cost of debt based on Market timing theory as explained in the study of Frank and Goyal (2009) suggesting that firms expecting increase in the inflation rate, they decide to employ more debt, because firms realize that the present cost of debt is cheaper. Trade-off theory also views the same relationship, and adds that the real value of tax shield is 
higher when inflation rises resulting to firms absorbing more debt to get more tax benefits (Taggart Jr, 1985). Both theories agree that expected inflation has a positive impact on leverage. Therefore, this paper assumes that expected inflation and financial leverage have direct relationship.

\section{Data and Methodology}

This research paper focuses on the Vietnamese banking industry, particularly, local commercial banks. Currently, there are 38 local commercial banks operating in Vietnam, however, due to some data limitations, this paper will only consider a panel yearly data consisting of 31 banks from 2009 to 2014. Dependent and independent variables will be primarily based on the audited financial statements of banks collected from Vietstock Finance website (http://finance.vietstock.vn/), while macroeconomic data like GDP and inflation are collected from Trading Economics website (http://www.tradingeconomics.com/). The list of the proposed banks to be studied can be found in Appendix 1.

- $H_{0}$ : Independent variables have no explanatory power on Vietnamese banks'leverage $\left(\beta_{i}=0\right)$

- $H_{1}$ : Independent variables have explanatory power on Vietnamese banks' leverage ( $\beta_{i}$ $\neq 0)$

The hypotheses are tested by estimating the following regression equations:

For the OLS regression:

$L E V_{i, t}=\beta_{0}+\beta_{1} S_{Z Z E_{i, t}}+\beta_{2}$ PROF $_{i, t}+\beta_{3}$ GROW $_{i, t}+\beta_{4} T A X_{i, t}+\beta_{5} R_{S S K_{i, t}}+\beta_{6} S_{T K} K_{i, t}+$ $\beta_{7} E C O N_{i, t}+\beta_{\delta} I N F_{i, t}+\varepsilon_{i, t}$;

And for both the FE and RE regressions:

$$
\begin{aligned}
& \mathrm{LEV}_{i, t}=\beta_{1} \mathrm{SIZEi}_{, t}+\beta_{2} \mathrm{PROFi}_{, t}+\beta_{3} \mathrm{GROW}_{i, t}+\beta_{4} T A X_{i, t}+\beta_{5} \mathrm{RISK}_{i, t}+\beta_{6} \mathrm{STK}_{i, t}+\beta_{7} \mathrm{ECON}_{i, t}+ \\
& \beta_{8} I N F_{i, t}+v i+\varepsilon_{i, t}
\end{aligned}
$$

The relationship among bank-specific, and economic and financial market explanatory variables over Vietnamese banks' degree of leverage will be tested using a multivariable regression model to determine the significance, sign and magnitude of the effect of each variable on leverage ratio. The methodology will be carried out by initially checking multicollinearity problem to see if independent variables are highly correlated with each another. The objective is to detect near multicollinearity (i.e. correlation which is higher than 0.8 ) using the correlation matrix. Detecting and solving multicollinearity is important, because:

a) highly correlated variables make it difficult to observe individual positive or negative effect of variables to the general fit of the regression, which may result in having a high R2 making the regression equation look seemingly good, but with spurious results;

b) the regression will be highly sensitive to every small changes in the regression 
specification, making adding or removing regressors lead to larger change in coefficient values or the significance of other explanatory variables; and

c) the problem of multicollinearity will lead to inappropriate conclusions for the regression equation that can reduce the accuracy of expected results.

Another test that the paper will perform is the White test to detect the presence of heteroscedasticity or the presence of inconstant variance. Although, heteroscedasticity does not cause OLS coefficients to be biased, it can cause OLS estimates of the variance (i.e., standard errors) of the coefficients to be biased, which can be possibly above or below the true variance. Biased standard errors lead to biased inference of the data, making the estimated results of hypothesis tests possibly inaccurate. Once detected, the study will undertake the heteroscedasticity-corrected OLS function to correct heteroscedasticity problem.

The paper will then run two classes of estimator approaches to determine which model fits the panel data. First, the FE model assumes correlation between error term and variables. The model eliminates the specific effect of time-invariant features to determine the net effect of the explanatory variables and also to take into account the distinctiveness of these features by not correlating them with other individual characteristics. Second, the RE model on the other hand assumes that the variations across the entities are random and uncorrelated with the explanatory variables. This model also considers the inclusion of the time-invariant variables. This paper will perform the Hausman test on the panel data set to examine the suitability of either the FE model or the RE model.

The paper examines factors that explain capital structure decision of banks with particular focus on the amount of debt they carry. There are 8 determinants to be tested, including 5 bank-specific factors: size (SIZE), profits (PROF), growth rate (GROW), taxation (TAX), and business risk (RISK); and 3 economic and financial market variables: stock market condition (STK), economic condition (ECON), and inflation (INF). These variables are tested against bank leverage (LEV), and the general null and alternative hypotheses are:

The Hausman test compares the fixed and random effects estimates of coefficients, in two related hypotheses:

- $H_{0}$ : The random effects are uncorrelated with the explanatory variables (i.e., RE model is preferred)

- $H_{1}$ : The random effects are correlated with the explanatory variables (i.e., FE model is preferred)

After ensuring that the panel data is free from the above problems and has determined its characteristics, the study will then run and interpret the final results of the regression. Findings will be analyzed based on their consistency with the above mentioned theories, and previous findings of our related literature. 


\section{Empirical Results}

Table 2 illustrates the summary statistics of Vietnamese banks showing the average, median, standard deviation, and the minimum and maximum values for all data sets. For all the banks' group, the average value for leverage is $89 \%$, which means that $89 \%$ of Vietnamese banks' assets is debt, while the disparity within this data set is $8 \%$. For the size, the average total asset is VND123.50 trillion and the disparity within the banks is about VND156.31 trillion. For the profitability factor, the industry's average is around $2 \%$, while the standard deviation is $1 \%$. The average growth of the banking industry in terms of value are about VND2.16 trillion, while the disparity among banks VND3.25trillion. Moreover, the average tax rate for all banks are about $17 \%$, with a standard deviation of $1 \%$ within the industry. Lastly, for the average risk of Vietnamese banking industry is around VND37.44 billion in possible losses with a standard deviation of VND27.58 billion.

Table 2. Summary statistics of Vietnamese banks

\begin{tabular}{|c|c|c|c|c|c|c|c|c|c|c|c|}
\hline Catego & ory & & LEV & SIZE & PROF & GROW & TAX & RISK & STK & ECON & INF \\
\hline \multirow{5}{*}{\multicolumn{2}{|c|}{ 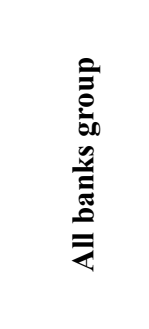 }} & Mean & 0.89 & 123503 & 0.02 & 2158 & 0.17 & 37.44 & 465.83 & 0.11 & 0.09 \\
\hline & & Median & 0.91 & 64172 & 0.02 & 755 & 0.17 & 27.48 & 489.72 & 0.10 & 0.08 \\
\hline & & $\begin{array}{l}\text { Standard } \\
\text { deviation }\end{array}$ & 0.08 & 156308 & 0.01 & 3251 & 0.07 & 27.58 & 64.52 & 0.04 & 0.05 \\
\hline & & Min & 0.39 & 2524 & 0.00 & 35 & 0.01 & 5.99 & 351.55 & 0.07 & 0.04 \\
\hline & & Max & 0.97 & 729564 & 0.06 & 15070 & 0.39 & 122.76 & 545.63 & 0.17 & 0.19 \\
\hline \multirow{5}{*}{ 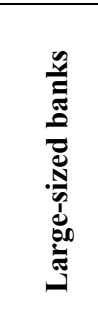 } & \multirow{5}{*}{$\stackrel{0}{\bar{z}}$} & Mean & 0.92 & 313058 & 0.02 & 6059 & 0.16 & 72.18 & 465.83 & 0.11 & 0.09 \\
\hline & & Median & 0.92 & 243004 & 0.02 & 5155 & 0.15 & 71.80 & 489.72 & 0.10 & 0.08 \\
\hline & & $\begin{array}{l}\text { Standard } \\
\text { deviation }\end{array}$ & 0.03 & 197723 & 0.01 & 4307 & 0.08 & 29.46 & 65.02 & 0.04 & 0.05 \\
\hline & & Min & 0.80 & 54492 & 0.00 & 428 & 0.01 & 20.70 & 351.55 & 0.07 & 0.04 \\
\hline & & $\operatorname{Max}$ & 0.96 & 729564 & 0.03 & 15070 & 0.39 & 122.76 & 545.63 & 0.17 & 0.19 \\
\hline \multirow{5}{*}{ 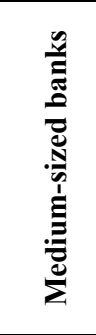 } & \multirow{5}{*}{ 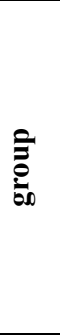 } & Mean & 0.91 & 91015 & 0.01 & 1277 & 0.16 & 33.22 & 465.83 & 0.11 & 0.09 \\
\hline & & Median & 0.92 & 79889 & 0.01 & 991 & 0.17 & 31.48 & 489.72 & 0.10 & 0.08 \\
\hline & & $\begin{array}{l}\text { Standard } \\
\text { deviation }\end{array}$ & 0.03 & 55144 & 0.01 & 1017 & 0.07 & 13.27 & 64.84 & 0.04 & 0.05 \\
\hline & & Min & 0.78 & 10729 & 0.00 & 105 & 0.01 & 10.23 & 351.55 & 0.07 & 0.04 \\
\hline & & Max & 0.96 & 281019 & 0.03 & 4563 & 0.30 & 67.55 & 545.63 & 0.17 & 0.19 \\
\hline \multirow{5}{*}{\multicolumn{2}{|c|}{ 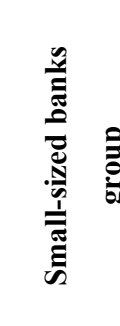 }} & Mean & 0.84 & 26919 & 0.02 & 365 & 0.18 & 18.15 & 465.83 & 0.11 & 0.09 \\
\hline & & Median & 0.86 & 22505 & 0.02 & 317 & 0.19 & 17.81 & 489.72 & 0.10 & 0.08 \\
\hline & & $\begin{array}{l}\text { Standard } \\
\text { deviation }\end{array}$ & 0.10 & 16267 & 0.01 & 225 & 0.06 & 6.02 & 64.79 & 0.04 & 0.05 \\
\hline & & Min & 0.39 & 2524 & 0.00 & 35 & 0.01 & 5.99 & 351.55 & 0.07 & 0.04 \\
\hline & & Max & 0.97 & 69263 & 0.06 & 970 & 0.38 & 31.15 & 545.63 & 0.17 & 0.19 \\
\hline
\end{tabular}

Source: Collected by authors 


\section{Macrothink

This study initially tabulated the correlation matrix to check for correlation problems. If the correlation value is equal or larger than 0.8 , the study decides to remove one of two variables based on the higher p-value using the OLS model. White test is also employed to check for heteroscedasticity problems. All the findings presented in the study were heteroscedasticity-corrected models. The study also used the Hausman test to check which model is preferable between FE and RE models. Overall, among the three models used, the highest log-likelihood value was utilized to decide which model is preferable. Table 3 summarized the hypothesized and empirical relationships between leverage and its explanatory variables.

Table 3. Summary of relationships between determinants and leverage

\begin{tabular}{|c|c|c|c|c|c|}
\hline \multirow{2}{*}{ Variable } & \multirow{2}{*}{$\begin{array}{c}\text { Hypothesized } \\
\text { relationship }\end{array}$} & All banks & $\begin{array}{c}\text { Large-sized } \\
\text { banks }\end{array}$ & $\begin{array}{c}\text { Medium-sized } \\
\text { banks }\end{array}$ & $\begin{array}{c}\text { Small-sized } \\
\text { banks }\end{array}$ \\
\cline { 3 - 6 } & $(+)$ & $(+)$ & $(+)$ & $(+)$ & $(+)$ \\
\hline SIZE & $(-)$ & -- & $(-)$ & -- & -- \\
\hline PROF & $(+)$ & -- & -- & -- & $(-)$ \\
\hline GROW & $(+)$ & -- & -- & -- & -- \\
\hline TAX & $(-)$ & -- & -- & -- & -- \\
\hline STSK & $(-)$ & $(-)$ & -- & -- & $(-)$ \\
\hline ECON & $(-)$ & $(-)$ & -- & -- & $(-)$ \\
\hline INF & $(+)$ & -- & -- & -- & -- \\
\hline
\end{tabular}

Note: (+) means positive relationship; (-) means negative relationship; -- means insignificant

\subsection{Check for Correlation}

Table 4 illustrates the correlation matrix. For all banks group, RISK was removed from the model, because of its correlation with both SIZE and GROW variables. For large-sized banks group, we initially remove RISK variable, because of its correlation with both GROW and SIZE factors. However, GROW and SIZE also have correlation with each other. The study decided to remove GROW because of its higher p-value over SIZE based on the OLS model. For medium-sized banks group, the matrix shows that there is a correlation between RISK and GROW variables. The paper decided to omit RISK because of its higher $p$-value over GROW based on the OLS model. Lastly, for small-sized banks group, there also exists correlation between RISK and GROW, OLS model result indicates that RISK has higher p-value and should be removed. 
Table 4. Correlation matrix of variables

\begin{tabular}{|c|c|c|c|c|c|c|c|c|c|}
\hline Category & Variables & SIZE & PROF & GROW & TAX & RISK & STK & ECON & INF \\
\hline \multirow{8}{*}{ 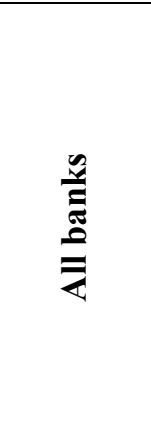 } & SIZE & 1.0000 & -0.1478 & 0.7728 & -0.2796 & 0.8482 & 0.0118 & 0.0899 & 0.0972 \\
\hline & PROF & & 1.000 & 0.2376 & 0.1618 & 0.2819 & -0.2320 & 0.1144 & 0.0215 \\
\hline & GROW & & & 1.0000 & -0.1493 & 0.9682 & -0.0509 & 0.0926 & 0.0632 \\
\hline & TAX & & & & 1.0000 & -0.1411 & -0.1433 & -0.1069 & 0.3063 \\
\hline & RISK & & & & & 1.0000 & -0.0654 & 0.1001 & 0.0618 \\
\hline & STK & & & & & & 1.0000 & -0.9121 & 0.4829 \\
\hline & ECON & & & & & & & 1.0000 & 0.6823 \\
\hline & INF & & & & & & & & 1.0000 \\
\hline \multirow{8}{*}{ 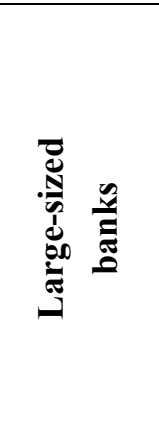 } & SIZE & 1.0000 & 0.1331 & 0.8851 & -0.4579 & 0.8920 & 0.0312 & 0.1383 & 0.1852 \\
\hline & PROF & & 1.000 & 0.4486 & 0.2206 & 0.5257 & -0.2774 & 0.2104 & 0.0560 \\
\hline & GROW & & & 1.0000 & -0.2815 & 0.9842 & -0.0926 & 0.2084 & 0.1773 \\
\hline & TAX & & & & 1.0000 & -0.2422 & -0.0984 & -0.1722 & 0.3001 \\
\hline & RISK & & & & & 1.0000 & -0.0923 & 0.1982 & 0.1705 \\
\hline & STK & & & & & & 1.0000 & -0.9121 & 0.4829 \\
\hline & ECON & & & & & & & 1.0000 & 0.6823 \\
\hline & INF & & & & & & & & 1.0000 \\
\hline \multirow{8}{*}{ 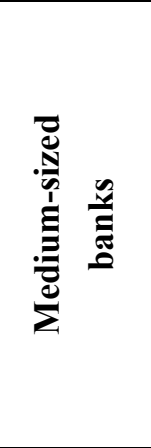 } & SIZE & 1.0000 & -0.1806 & 0.6982 & -0.2517 & 0.7345 & -0.0075 & 0.2024 & 0.1877 \\
\hline & PROF & & 1.000 & 0.4422 & 0.2023 & 0.4780 & -0.0673 & -0.1287 & 0.2254 \\
\hline & GROW & & & 1.0000 & 0.0551 & 0.9766 & -0.0881 & 0.1108 & 0.0164 \\
\hline & TAX & & & & 1.0000 & -0.0033 & -0.2040 & -0.0685 & 0.3314 \\
\hline & RISK & & & & & 1.0000 & -0.0598 & 0.0965 & 0.0074 \\
\hline & STK & & & & & & 1.0000 & -0.9121 & 0.4829 \\
\hline & ECON & & & & & & & 1.0000 & 0.6823 \\
\hline & INF & & & & & & & & 1.0000 \\
\hline \multirow{8}{*}{ 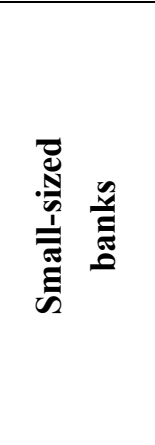 } & SIZE & 1.0000 & -0.6010 & 0.2627 & -0.3691 & 0.2192 & 0.0407 & 0.1247 & 0.1395 \\
\hline & PROF & & 1.000 & 0.5057 & 0.1252 & 0.5261 & -0.3240 & 0.2106 & 0.0455 \\
\hline & GROW & & & 1.000 & -0.1653 & 0.9817 & -0.3644 & 0.3644 & 0.1835 \\
\hline & TAX & & & & 1.000 & -0.1054 & -0.1236 & -0.0948 & 0.2954 \\
\hline & RISK & & & & & 1.000 & -0.3573 & 0.3509 & 0.1648 \\
\hline & STK & & & & & & 1.000 & -0.9121 & 0.4829 \\
\hline & ECON & & & & & & & 1.000 & 0.6823 \\
\hline & INF & & & & & & & & 1.000 \\
\hline
\end{tabular}

Source: Collected and organized by authors.

\subsection{OLS Model Results and Interpretation}

\subsubsection{All Banks Group}

Table 5 shows three regression results for all bank group using the OLS, FE and RE models. This study used the Hausman test to decide between the FE and RE models. For this table, p-value less than significance level of $1 \%$ made this study chose the FE model to represent 
the relationship between bank's leverage and its determinants. The OLS model yielded five significant variables: banks size (SIZE), profitability (PROF), growth rate (GROW), Vietnamese stock market (STK), and the country's economy (ECON). On one hand, the FE model has three variables: banks size, stock market, and Vietnam's economy.

Table 5. Summary of analysis results of OLS, FE and RE models for all banks group

\begin{tabular}{|c|c|c|c|}
\hline Variables & $\begin{array}{c}\text { Heteroscedasticity-corrected } \\
\text { OLS model }\end{array}$ & FE model & RE model \\
\hline Constant & $\begin{array}{l}0.454 * * * \\
(0.000)\end{array}$ & $\begin{array}{l}0.055 \\
(0.719)\end{array}$ & $\begin{array}{l}0.302 * * \\
(0.030)\end{array}$ \\
\hline SIZE & $\begin{array}{l}0.039 * * * \\
(0.000)\end{array}$ & $\begin{array}{l}0.086 * * * \\
(0.000)\end{array}$ & $\begin{array}{l}0.062 * * * \\
(0.000)\end{array}$ \\
\hline PROF & $\begin{array}{l}-1.822 * * * \\
(0.000)\end{array}$ & $\begin{array}{l}-0.626 \\
(0.190)\end{array}$ & $\begin{array}{l}-1.021 * * \\
(0.030)\end{array}$ \\
\hline GROW & $\begin{array}{l}-0.000 * * * \\
(0.002)\end{array}$ & $\begin{array}{l}-0.000 \\
(0.730)\end{array}$ & $\begin{array}{l}-0.000^{*} \\
(0.058)\end{array}$ \\
\hline TAX & $\begin{array}{l}0.004 \\
(0.925)\end{array}$ & $\begin{array}{l}-0.076 \\
(0.101)\end{array}$ & $\begin{array}{l}-0.077 \\
(0.106)\end{array}$ \\
\hline STK & $\begin{array}{l}-0.000 * * * \\
(0.002)\end{array}$ & $\begin{array}{l}-0.001 * * * \\
(0.000)\end{array}$ & $\begin{array}{l}-0.001 * * * \\
(0.000)\end{array}$ \\
\hline ECON & $\begin{array}{l}-1.568 * * * \\
(0.008)\end{array}$ & $\begin{array}{l}-1.967 * * * \\
(0.000)\end{array}$ & $\begin{array}{l}-1.346 * * * \\
(0.000)\end{array}$ \\
\hline INF & $\begin{array}{l}-0.072 \\
(0.245) \\
\end{array}$ & $\begin{array}{l}0.031 \\
(0.684)\end{array}$ & $\begin{array}{l}-0.0432 \\
(0.077) \\
\end{array}$ \\
\hline $\mathbf{R}^{2}$ & 0.618 & 0.889 & \\
\hline White test p-value & $\begin{array}{l}134.172 * * * \\
(0.000)\end{array}$ & & \\
\hline Log-likelihood & -335.220 & 415.930 & 287.193 \\
\hline Hausman p-value & & & $\begin{array}{l}24.842 * * * \\
(0.001)\end{array}$ \\
\hline
\end{tabular}

Note: $*, * *$ and $* * *$ are significance at $10 \%, 5 \%$ and $1 \%$ levels, respectively; p-values are in parentheses

Source: Collected and organized by authors.

The banks' size variable (SIZE), which represents total assets of all Vietnamese banks under study, has positive relationship with leverage based on both the OLS and the FE models. This finding held up with our prediction, as well as the findings of Vatavu (2012), and Strebulaev and Kurshev (2006). These studies discover that banks with huge asset base have easier access to capital markets because of their longstanding reputation. The paper suggests that banks capitalize on their reputation and a stronger marketing strategy to attract more individual depositors and easily get loans from interbank sources or from the government.

Banks' profitability (PROF), on the other hand is negatively associated with leverage. This result is consistent with the findings of Aremu et al. (2013) and the Pecking order theory, 
which explained that highly profitable banks prefer internal sources of financing as an alternative to borrowing from external sources. The more retained earnings are employed, the lesser is the debt ratio. This study observed that most Vietnamese banks have low dividend payouts, about 10 - 13.5\% (Linh, 2015), because retained earnings are mostly used for capital expenditures and re-investment purposes. Furthermore, internal sources have lower cost than external ones, that's why banks rarely absorb debts when they have abundant internal funding sources. In this paper's view, Vietnamese banks should find the balance in using retained earnings and in acquiring a healthy amount of debt to maximize leveraging, and earn more after settling interest and principal payments. A well-balanced capital structure also helps banks in attracting and satisfying investors who prefer dividend from time to time.

For growth rate variable (GROW), the regression coefficient of this variable is negative under the OLS model, which is actually in contrast with paper's hypothesis that growth rate is positively related to financial leverage. However, this result supports the studies of Barclay et al. (2006), and Pandey (2001), which explained that when firms foresee the potential growth from their investments, companies prefer using their own capital over funds coming from creditors to avoid decisions being affected by creditors. This explanation is also related to the Agency cost theory. Thus, this paper suggests that banks should avoid borrowing too much money when experiencing a greater degree of profitability; because as Mayers (1977) put it, sometimes higher profit leads to higher risk due to the greater uncertainty connected with expansion.

For stock market condition variable (STK), both the OLS and FE models result indicate a negative relationship between stock market conditions and debt ratio. This is consistent with the paper's hypothesis and conforms with the previous studies of Frank and Goyal (2009), and Welch (2004) which suggested that firms usually employ less debt when their market valuations are high in booming stock condition period. Also, when large amounts of deposits from customer are transferred from banks to investing stock market, lower deposits decreases banks' liability, which leads to increase in the stock markets because of more liquidity. It is recommended that Vietnamese banks should join the stock market so that they can balance their leverage by also gaining equity on the capital structure, which helps banks' leverage to be stable. Currently, most Vietnamese banks are not listed on stock exchanges, one of the reasons why stock market fluctuations do not affect much of their valuations.

For the economic condition variable (ECON), the regression shows a negative coefficient for both OLS and FE models, which means that banks' leverage is inversely affected by economic condition. This result supports the paper's prediction, and follows the Pecking order theory. This finding also confirms the study of Dincergok and Yalciner (2011) explaining that in a good economic condition, most firms get large profit and they prefer using internal source of financing instead of borrowing from external sources. Furthermore, banks' role of playing financial mediator pushes investment and borrowing from banks in a boom economy. This increases current assets, which reduces banks' leverage. Moreover, a booming economy encourages banks' customers to transfer their capital from savings to investing in other higher profitable projects, which slightly reduces banks' liability. 
In comparing the results of the OLS and FE models, this research favors the results of the FE model as the better fitting model for all banks group, because of the higher log-likelihood value.

\subsubsection{Large-sized Banks Group}

Table 6 again illustrates three regression results for large-sized Vietnamese bank group using the OLS, FE and RE models. The Hausman test prefers the RE model over the FE model because of the insignificant p-value. Both the OLS and RE models have similar two significant explanatory variables: banks size and profitability. Consistent with earlier findings for all bank group, size variable is positively related with debt ratio for both the OLS and FE models. This implies that bigger total assets of banks lead to higher debt ratio. This result is again consistent with the findings of Vatavu (2012), and Strebulaev and Kurshev (2006) explaining the higher number of depositors, the easier access to loans. The study recommends that large banks capitalize on their market network to attract more depositors and easily get loans from interbank sources or from the government with lower interest.

Table 6. Summary of analysis results of OLS, FE and RE models for large-sized banks group

\begin{tabular}{|c|c|c|c|}
\hline Variables & OLS model & FE model & RE model \\
\hline Constant & $\begin{array}{l}0.643 * * * \\
(0.000)\end{array}$ & $\begin{array}{l}0.465^{*} \\
(0.060)\end{array}$ & $\begin{array}{l}0.605 * * * \\
(0.000)\end{array}$ \\
\hline SIZE & $\begin{array}{l}0.024 * * * \\
(0.000)\end{array}$ & $\begin{array}{l}0.036 * * \\
(0.040)\end{array}$ & $\begin{array}{l}0.025 * * * \\
(0.000)\end{array}$ \\
\hline PROF & $\begin{array}{l}-1.160 * * \\
(0.021)\end{array}$ & $\begin{array}{l}-1.911 * * * \\
(0.008)\end{array}$ & $\begin{array}{l}-1.395 * * \\
(0.012)\end{array}$ \\
\hline TAX & $\begin{array}{l}-0.021 \\
(0.698) \\
\end{array}$ & $\begin{array}{l}0.026 \\
(0.606)\end{array}$ & $\begin{array}{l}0.000 \\
(0.997) \\
\end{array}$ \\
\hline STK & $\begin{array}{l}-0.000 \\
(0.137)\end{array}$ & $\begin{array}{l}-0.000 \\
(0.138)\end{array}$ & $\begin{array}{l}0.000 \\
(0.137) \\
\end{array}$ \\
\hline ECON & $\begin{array}{l}-0.325 \\
(0.334) \\
\end{array}$ & $\begin{array}{l}-0.461 \\
(0.304) \\
\end{array}$ & $\begin{array}{l}-0.292 \\
(0.358) \\
\end{array}$ \\
\hline INF & $\begin{array}{l}-0.0230 \\
(0.818) \\
\end{array}$ & $\begin{array}{l}-0.015 \\
(0.867)\end{array}$ & $\begin{array}{l}-0.025 \\
(0.786) \\
\end{array}$ \\
\hline $\mathbf{R}^{2}$ & 0.429 & 0.651 & \\
\hline White test p-value & $\begin{array}{l}28.567 \\
(0.195) \\
\end{array}$ & & \\
\hline Log-likelihood & 122.355 & 134.184 & 122.164 \\
\hline Hausman p-value & & & $\begin{array}{l}9.413 \\
(0.152)\end{array}$ \\
\hline
\end{tabular}

Note: ${ }^{*}, * *$ and ${ }^{* * *}$ are significance at $10 \%, 5 \%$ and $1 \%$ levels, respectively; p-values are in parentheses

Source: Collected and organized by authors.

Profitability variable for large banks consistently has negative effects on leverage. This finding is again in-line with the initial result for all bank groups, consistent with the Pecking 
order theory, and related to the research of Aremu et al. (2013) that profitable banks have less debt ratio. Following this concept, it is suggested that large Vietnamese banks with higher profit continue to use internal capital in the form of retained earnings and additional equity, to minimize borrowing from external sources.

In comparing the results of the OLS and RE models, this study favors the findings of the OLS model as the better fitting model for large Vietnamese banks group, because of the higher log-likelihood value.

\subsubsection{Medium-sized Banks Group}

Table 7 again illustrates three regression results for medium-sized Vietnamese bank group using the OLS, FE and RE models. The Hausman test prefers the RE model over the FE model, because of the insignificant p-value. Both the OLS and RE models again have similar two significant explanatory variables: banks size and profitability, which is similar with the results from the large bank group. The size factor is again positively related with the leverage

Table 7. Summary of analysis results of OLS, FE and RE models for medium-sized banks group

\begin{tabular}{|c|c|c|c|}
\hline Variables & OLS model & FE model & RE model \\
\hline Constant & $\begin{array}{l}0.235 \\
(0.223)\end{array}$ & $\begin{array}{l}0.494 \\
(0.041)\end{array}$ & $\begin{array}{l}0.2686 \\
(0.168)\end{array}$ \\
\hline SIZE & $\begin{array}{l}0.046 * * * \\
(0.000)\end{array}$ & $\begin{array}{l}0.036 * * \\
(0.020)\end{array}$ & $\begin{array}{l}0.045 * * * \\
(0.000)\end{array}$ \\
\hline PROF & $\begin{array}{l}-1.181 \\
(0.123) \\
\end{array}$ & $\begin{array}{l}-2.608 * * \\
(0.013)\end{array}$ & $\begin{array}{l}-1.3454 * \\
(0.086)\end{array}$ \\
\hline GROW & $\begin{array}{l}-0.000 \\
(0.374)\end{array}$ & $\begin{array}{l}0.000 \\
(0.457)\end{array}$ & $\begin{array}{l}-0.000 \\
(0.497)\end{array}$ \\
\hline TAX & $\begin{array}{l}0.084 \\
(0.119) \\
\end{array}$ & $\begin{array}{l}0.069 \\
(0.299) \\
\end{array}$ & $\begin{array}{l}0.0801 \\
(0.142) \\
\end{array}$ \\
\hline STK & $\begin{array}{l}-0.000 \\
(0.216) \\
\end{array}$ & $\begin{array}{l}-0.000 \\
(0.157) \\
\end{array}$ & $\begin{array}{l}-0.000 \\
(0.187) \\
\end{array}$ \\
\hline ECON & $\begin{array}{l}-0.340 \\
(0.300) \\
\end{array}$ & $\begin{array}{l}-0.591 \\
(0.183) \\
\end{array}$ & $\begin{array}{l}-0.369 \\
(0.261) \\
\end{array}$ \\
\hline INF & $\begin{array}{l}-0.121 \\
(0.175)\end{array}$ & $\begin{array}{l}-0.083 \\
(0.365)\end{array}$ & $\begin{array}{l}-0.118 \\
(0.177)\end{array}$ \\
\hline $\mathbf{R}^{2}$ & 0.663 & 0.743 & \\
\hline White test p-value & $\begin{array}{l}39.070 \\
(0151)\end{array}$ & & \\
\hline Log-likelihood & 166.287 & 175.235 & 166.258 \\
\hline Hausman p-value & & & $\begin{array}{l}8.029 \\
(0.330)\end{array}$ \\
\hline
\end{tabular}

Note: ${ }^{*}, * *$ and ${ }^{* * *}$ are significance at $10 \%, 5 \%$ and $1 \%$ levels, respectively; $p$-values are in parentheses

Source: Collected and organized by authors. 
ratio of medium-sized banks for both the OLS and FE models consistent with the earlier findings for all bank and large-sized bank groups. This result is also related with the explanations of Vatavu (2012), and Strebulaev and Kurshev (2006). The study suggests that medium-sized Vietnamese banks should attract more depositors, and use lower interest loans whenever necessary for quicker expansions. This is because medium-sized banks sometimes are ignored by the equity markets for reasons of instability and unproven track records.

The factor profitability based on the FE model is again negatively related with leverage, which is in-line with the initial results for all bank and large-sized bank groups. This also conforms to the Pecking order theory, and consistent to the research of Aremu et al. (2013) that profitable banks have less debt ratio. To balance the initial suggestion of encouraging medium-sized banks to borrow to become bigger, this paper additionally recommends that these banks should maintain a healthy amount of debt that will not sacrifice profitability by constantly monitoring their cash flows to cover interests and principal payments. Once they maintained a consistent period of profitability, they should start using internal sources of funding to continue their profitable operations.

In comparing the results of the OLS and RE models, this paper again favors the findings of the OLS model as the better fitting model for medium Vietnamese banks group, because of the RE model has lower log-likelihood value.

\subsubsection{Small-sized Banks Group}

Table 8 shows three regression results for small-sized bank group using the OLS, FE and RE models. The Hausman test prefers the RE model over the FE model because of insignificant p-value. The OLS model yielded four significant variables: banks size, profitability, stock market conditions, and the country's economy. On one hand, the RE model also has four variables, but growth rate is significant instead of profitability.

The size factor for small-sized Vietnamese bank is again positively related with the leverage ratio based on both the OLS and RE models. This result is in accordance with the earlier findings for all bank, large-sized bank and medium-sized bank groups. This finding is again related with the initial explanations of Vatavu (2012), and Strebulaev and Kurshev (2006). However, this paper posits that one of the reason why small-sized Vietnamese banks also have a higher leverage because like their medium-sized counterparts, small banks are commonly ignored by investors in the equity markets for reasons of illiquidity and instability, pushing them to rely on attracting more depositors, and borrow funds even to the point of experiencing relatively higher interest rates. For small Vietnamese banks, the factor profitability based on the OLS model is again negatively related with their debt ratio, which is in-line with the initial results for all bank, large-sized bank and medium-sized bank groups. This also conforms to the research of Aremu et al. (2013). As per the recommendations for medium-sized banks, small Vietnamese banks should also borrow money to become bigger. However, small banks face bigger problems of illiquidity that may sometimes lead to counterproductive borrowings. This paper again recommends that small banks maintain a healthy amount of debt that will not sacrifice profitability by constantly monitoring their cash flows to cover interests and principal payments. Once small Vietnamese banks maintained a 
consistent period of profitability, they should start using internal sources of funding to continue profitable operations.

Table 8. Summary of analysis results of OLS, FE and RE models for small-sized banks group

\begin{tabular}{|c|c|c|c|}
\hline Variables & $\begin{array}{c}\text { Heteroscedasticity-corrected } \\
\text { OLS model }\end{array}$ & FE model & RE model \\
\hline Constant & $\begin{array}{l}0.062 \\
(0.770)\end{array}$ & $\begin{array}{l}-0.676 * * \\
(0.041)\end{array}$ & $\begin{array}{l}-0.642 * * \\
(0.040)\end{array}$ \\
\hline SIZE & $\begin{array}{l}0.088 * * * \\
(0.000)\end{array}$ & $\begin{array}{l}0.164 * * * \\
(0.000)\end{array}$ & $\begin{array}{l}0.164 * * * \\
(0.000)\end{array}$ \\
\hline PROF & $\begin{array}{l}-1.842 * * \\
(0.033)\end{array}$ & $\begin{array}{l}1.3661 \\
(0.1820)\end{array}$ & $\begin{array}{l}1.1862 \\
(0.227)\end{array}$ \\
\hline GROW & $\begin{array}{l}0.000 \\
(0.869)\end{array}$ & $\begin{array}{l}-0.000 * \\
(0.094)\end{array}$ & $\begin{array}{l}-0.000 * \\
(0.086)\end{array}$ \\
\hline TAX & $\begin{array}{l}0.056 \\
(0.355)\end{array}$ & $\begin{array}{l}-0.224 \\
(0.108)\end{array}$ & $\begin{array}{l}-0.229 \\
(0.102)\end{array}$ \\
\hline STK & $\begin{array}{l}-0.000 * * * \\
(0.000)\end{array}$ & $\begin{array}{l}-0.002 * * * \\
(0.000)\end{array}$ & $\begin{array}{l}-0.002 \\
(0.000)\end{array}$ \\
\hline ECON & $\begin{array}{l}-1.936 * * * \\
(0.000)\end{array}$ & $\begin{array}{l}-3.629 * * * \\
(0.000)\end{array}$ & $\begin{array}{l}-3.653 * * * \\
(0.000)\end{array}$ \\
\hline INF & $\begin{array}{l}0.018 \\
(0.895)\end{array}$ & $\begin{array}{l}0.145 \\
(0.320)\end{array}$ & $\begin{array}{l}0.143 \\
(0.309)\end{array}$ \\
\hline $\mathbf{R}^{2}$ & 0.761 & 0.920 & \\
\hline White test p-value & $\begin{array}{l}65.554 * * * \\
(0.000)\end{array}$ & & \\
\hline Log-likelihood & -128.735 & 151.788 & 104.018 \\
\hline Hausman p-value & & & $\begin{array}{l}1.753 \\
(0.972)\end{array}$ \\
\hline
\end{tabular}

Note: $*, * *$ and ${ }^{* * *}$ are significance at $10 \%, 5 \%$ and $1 \%$ levels, respectively; p-values are in parentheses

Source: Collected and organized by authors.

The regression coefficient of the growth rate variable is negative under the RE model, which is similar with the all bank group result, but do not conform to the paper's hypothesis. However, this finding is again accordance with the Agency cost theory and the studies of Barclay et al. (2006), and Pandey (2001) explaining that companies prefer using their own capital over funds coming from debtors. This is particularly true for small Vietnamese banks, because it is riskier for them to borrow compared to the more stable large and medium-sized banks, because of lower total assets, and higher interest payments. Small banks can also try tapping over-the-counter markets for equity issuance to fulfill their needs for external capital, pursue their investment choices, and diminish the risk of bankruptcy.

Both the OLS and FE models finding indicate a negative relationship between stock market conditions and leverage of small Vietnamese banks. This conforms to the paper's hypothesis, 
and consistent with the previous findings of all bank group. This result is also in-line with the previous studies of Frank and Goyal (2009), and Welch (2004), which explained that firms usually employ less debt when their market valuations are high in booming stock condition period. However, this does not entirely apply to most small banks in Vietnam, because most of them are not listed on local stock bourses. Small Vietnamese banks often rely on debt to carry-out operations and maintain liquidity. The local equity market is normally not an option for small banks, because they are often ignored by investors due to unstable reputations. This is also one of the reasons why stock market fluctuations do not affect small Vietnamese banks' valuations.

A negative coefficient for the economic condition variable in both OLS and RE models was also observed, which means that small Vietnamese banks' leverage is inversely affected by economic condition. This finding is in-line with the prediction of the paper, and also follows the Pecking order theory. The result also is in accordance with the explanations of Dincergok and Yalciner (2011), Frank and Goyal (2009), and Welch (2004), concluding that in a good economic condition, most firms, including small banks get higher than usual profits and they prefer using internal source of financing instead of borrowing from external sources, which is actually more costly for small Vietnamese banks. This paper suggests that booming economic conditions should be exploited by small banks through aggressive marketing of products, and expanding operations to take advantage of general economic liquidity. And if they have a chance of borrowing lower than usual interests, small banks can also obtain a small and manageable amount of debt in economic booms.

In comparing the results of the OLS and RE models, this paper again favors the findings of the RE model as the better fitting model for small Vietnamese banks group, because of the higher log-likelihood value.

\section{Conclusions and Limitations}

This research examines whether the eight factors determined, namely: size, profitability, growth rate, risk, tax rate, stock market condition, economic condition, and inflation affect the capital structure of Vietnamese banks. Three types of models are employed to satisfy this main objective: OLS model, FE model, and RE model. Aside from the regression models on all banks data, the study also divided the banks into three groups based on market capitalization (i.e., large-, medium-, and small-capitalization firms) to find out specific relationship and characteristics of each group with its bank's leverage.

Generally, findings of this study are in-line with previous empirical evidences. There are some factors that do not have significant influence on leverage (i.e., risk, tax rate and inflation); but for the other determinants, bank size has been the most consistent variable affecting leverage in all bank groups. The findings lead to the belief that the bigger banks have higher leverage, and this can be attributed to the advantage of stable reputation and larger network, making them have easier access to external capital, including debt on selected occasions. On the other hand, medium- and small-capitalization banks' leverage mostly comes from depositors instead of debtors because of their not consistent liquidity and instability. Profitability has significant negative impact on large banks group's leverage, 
suggesting that large Vietnamese banks prefer using internal source of financing (i.e., retained earnings).

Growth rates shows its negative impact on small banks group, assuming that small Vietnamese banks mostly use their profit for their investment rather than borrowing from external sources, which actually supports the Pecking order theory. Moreover, macroeconomic factors like stock market and economic conditions also have important influence on small-sized banks group. The study concludes that small banks tend to be more sensitive to every change of macroeconomic factors. In economic booms, small banks get more profit than usual, so they can utilize these profits for future investments, because this is the cheapest capital source. Furthermore, with a chance of accessing low interest capital in good economic condition, small banks can seize this opportunity to absorb a controllable amount of debt to increase their profit.

Although, the study provides a considerable amount of contributions, there still exist some limitations and suggested future studies to be improved in next researches. First, the study did not cover all of the Vietnamese banks, because some banks do not disclose their full financial statements. Also, the Vietnamese banking industry has just developed in recent years. These are the reasons why the study period is relatively short to fully cover the overall development of the Vietnamese banking industry. Future studies are suggested to increasing the data span and cover additional banks not included in the study. Second, M\&A activities have been an increasing trend in the Vietnamese banking industry. It is recommended that future researches particularly focus on banks who underwent M\&As. Third, most of the Vietnamese banks are still not publicly-listed. Future studies can try investigating the factors affecting the leverage and possibly even the profitability of private banks and family-controlled banks. Moreover, prospective research can also extend the number of significant determinants (i.e., ratios related to cash conversion cycles) to find out which factors is significantly important to determine Vietnamese bank's capital structure.

Regardless of these limitations, this paper can be considered as a pioneer in investigating the capital structure Vietnamese banks, and provides a good perspective to the banking industry. The paper is also helpful for Vietnamese academic researchers and banks' managers who want to study factors affecting banks' capital structure for their further researches and in making capital structure decisions, respectively.

\section{References}

Ali, M. S., Yadav, R., \& Jamal, A. (2013). Theories of capital structure: Analysis of capital structure determinants. International Research Journal of Management Science and Technology, 4(3), 695-704.

Anh, D.N.P. (2010). Determinants of capital structure and financial performance: A path analysis approach. Journal of Science and Technology, 5(40), 14-22.

Aremu, M. A., Ekpo, I. C., Mustapha, A. M., \& Adedoyin, S. I. (2013). Determinants of capital structure in Nigerian banking sector. International Journal of Academic Research in Economics and Management Sciences, 2(4), 27-43. https://doi.org/10.6007/ijarems/v2-i4/50 
Barclay, M.J., Morellec, E., \& Smith, Jr. C.W. (2006). On the debt capacity of growth options. Journal of Business, 79, 37-59. https://doi.org/10.2139/ssrn.271949

Canh, N. T., \& Cuong, N. T. (2011). The determinants of capital structure for Vietnam's seafood processing enterprises. Science \& Technology Development Journal, 14, 28-54.

Chen, L. \& Zhao, X. (2006). On the relation between the market-to-book ratio, growth opportunity, and leverage ratio. Finance Research Letters, 3(4), 253-266. https://doi.org/10.2139/ssrn.666845

Dincergok, B., \& Yalciner, K. (2011). Capital structure decisions of manufacturing firms in developing countries. Middle Eastern Finance and Economics, 12, 86-100.

Dung, T. T. T. (2015). Determinants of capital structure: An empirical study of Vietnamese listed firms (Master's Thesis). Available from Saint Mary's University Publications.

Frank, M. Z., \& Goyal, V. K. (2009). Capital structure decisions: Which factors are reliably important?. Financial Management, $\quad 38(1), \quad$ 1-37. https://doi.org/10.1111/j.1755-053x.2009.01026.x

Gertler, M., \& Gilchrist, S. (1993). The role of credit market imperfections in the monetary transmission mechanism: Arguments and evidence. Scandinavian Journal of Economics, 95, 43-63. https://doi.org/10.2307/3440134

Gropp, R., \& Heider, F. (2010). The determinants of bank capital structure. Review of Finance, 14(4), 587-622. https://doi.org/10.1093/rof/rfp030

Hoa, N., \& Kayani, Z. (2013). Determinants of banks' capital structure in Asia - A comparison amongst developed and developing countries (Master's Thesis). Available from Lund University Publications.

Jensen, M. C. (1986). Agency cost of free cash flow, corporate finance, and takeovers. The American Economic Review, 76(2), 323-329. https://doi.org/10.2139/ssrn.99580

Juca, M. N., De Sousa, A. F., \& Fishlow, A. (2012). Capital structure determinant's of North American banks and the compensation executive program - An empiric study on the actual systemic crisis. International Journal of Business and Management, 7(17), 13-26. https://doi.org/10.5539/ijbm.v7n17p13

Linh, H. P. M. (2015). Analysis of dividend policy of insurance and finance companies listed on Ho Chi Minh Stock Exchange (Master's Thesis). Available from Thang Long University Publications.

MacKinlay, A. (2013). (How) do taxes affect capital structure? (Master's Thesis). Available from University of Pennsylvania Publications. https://doi.org/10.2139/ssrn.2022518

Modigliani, F. \& Miller, M. H. (1963). Corporate income taxes and the cost of capital: A correction. American Economic Review, 53, 433-43.

Myers, S. C. (1977). Determinants of corporate borrowing. Journal of Financial Economics, 
$5,147-175$.

Octavia, M., \& Brown, R. (2010). Determinants of bank capital structure in developing countries: Regulatory capital requirement versus the standard determinants of capital structure. Journal of Emerging Markets, 15(1), 50-84.

Okuda, H., \& Nhung, L. T. P. (2012). Capital structure and investment behavior of listed companies in Vietnam: An estimation of the influence of government ownership. International Journal of Business and Information, 7(2), 137-164.

Osterberg, W. P., \& Thomson, J. B. (1991). The effect of subordinated debt and surety bonds on the cost of capital for banks and the value of federal deposit insurance. Journal of Banking \& Finance, 15(4-5), 939-953. https://doi.org/10.1016/0378-4266(91)90107-w

Pandey, I. M. (2001). Capital structure and the firm characteristics: Evidence from an emerging market (IIMA Working Paper). Available from University of Delhi Publications. https://doi.org/10.2139/ssrn.300221

Rajan, R. G., \& Zingales, L. (1995). What do we know about capital structure? Some evidence from international data. The Journal of Finance, 50(5), 1421-1460. https://doi.org/10.3386/w4875

Strebulaev, I. A., \& Kurshev, A. (2006). Firm size and capital structure. In EFA 2005 Moscow Meetings Paper.

Taggart Jr, R. A. (1985). Secular patterns in the financing of US corporations. In Corporate capital structures in the United States (pp. 13-80). University of Chicago Press.

Thu, L. T. K. (2012). Capital structure determinants of real estate firms listed on HOSE (Master's Thesis). Available from Da Nang University Publications.

Titman, S., \& Wessels, R. (1988). The determinants of capital structure choice. Journal of Finance, 43, 1-21. https://doi.org/10.1111/j.1540-6261.1988.tb02585.x

Vatavu, S. (2012). Determinants of capital structure: Evidence from Romanian manufacturing companies. Proceedings in ARSA-Advanced Research in Scientific Areas, (1), 670-673.

Welch, I. (2004). Capital structure and stock returns. Journal of Political Economy, 112(1), 106- 132. https://doi.org/10.2139/ssrn.298196

Williamson, O. (1988). Corporate finance and corporate governance. Journal of Finance, 43(3), 567-591. 


\section{Appendix}

Appendix 1. List of Banks Selected in the Study

In million USD (31/12/2014)

\begin{tabular}{|c|c|c|c|c|c|}
\hline No. & English Name & Abbreviation & $\begin{array}{c}\text { Total } \\
\text { Assets }\end{array}$ & $\begin{array}{l}\text { Total } \\
\text { Equity }\end{array}$ & $\begin{array}{c}\text { Year of } \\
\text { Establishm } \\
\text { ent } \\
\end{array}$ \\
\hline 1 & $\begin{array}{l}\text { Vietnam Bank for Agriculture and } \\
\text { Rural Development }\end{array}$ & Agribank & 34112 & 2295 & 1988 \\
\hline 2 & $\begin{array}{l}\text { Vietnam Joint Stock Commercial } \\
\text { Bank for Industry and Trade }\end{array}$ & Vietinbank & 30912 & 2583 & 1988 \\
\hline 3 & $\begin{array}{l}\text { Bank for Investment and } \\
\text { Development of Vietnam }\end{array}$ & BIDV & 30407 & 1556 & 1957 \\
\hline 4 & $\begin{array}{l}\text { Joint Stock Commercial Bank for } \\
\text { Foreign Trade of Vietnam }\end{array}$ & Vietcombank & 26978 & 2027 & 1963 \\
\hline 5 & $\begin{array}{l}\text { Saigon Joint Stock Commercial } \\
\text { Bank }\end{array}$ & $\mathrm{SCB}$ & 11325 & 616 & 1992 \\
\hline 6 & $\begin{array}{l}\text { Military Commercial Joint Stock } \\
\text { Bank }\end{array}$ & MBBank & 9374 & 774 & 1994 \\
\hline 7 & $\begin{array}{l}\text { Saigon Thuong Tin Commercial } \\
\text { Joint Stock Bank }\end{array}$ & Sacombank & 8874 & 845 & 1991 \\
\hline 8 & Asia Commercial Bank & ACB & 8398 & 580 & 1993 \\
\hline 9 & $\begin{array}{l}\text { Vietnam Technological and } \\
\text { Commercial Joint Stock Bank }\end{array}$ & Techcombank & 8225 & 701 & 1993 \\
\hline 10 & $\begin{array}{l}\text { Saigon-Hanoi Commercial Joint } \\
\text { Stock Bank }\end{array}$ & SHB & 7903 & 490 & 1993 \\
\hline 11 & $\begin{array}{l}\text { Vietnam Prosperity Commercial } \\
\text { Joint Stock Bank }\end{array}$ & VPBank & 7633 & 420 & 1993 \\
\hline 12 & $\begin{array}{l}\text { Vietnam } \quad \text { Export } \quad \text { Import } \\
\text { Commercial Joint Stock Bank }\end{array}$ & EIB & 7532 & 658 & 1989 \\
\hline 13 & $\begin{array}{l}\text { Maritime Commercial Joint Stock } \\
\text { Bank }\end{array}$ & MSB & 4880 & 442 & 1991 \\
\hline 14 & $\begin{array}{l}\text { LienViet Post Commercial Joint } \\
\text { Stock Bank }\end{array}$ & LPB & 4713 & 346 & 2008 \\
\hline 15 & $\begin{array}{l}\text { Ho Chi Minh City Housing } \\
\text { Development Bank }\end{array}$ & HDBank & 4653 & 415 & 1990 \\
\hline 16 & $\begin{array}{l}\text { Dong A Commercial Joint Stock } \\
\text { Bank }\end{array}$ & DongABank & 4073 & 264 & 1993 \\
\hline 17 & $\begin{array}{l}\text { Vietnam International Commercial } \\
\text { Joint Stock Bank }\end{array}$ & VIB & 3771 & 397 & 1996 \\
\hline 18 & $\begin{array}{l}\text { Southeast Asia Commercial Joint } \\
\text { Stock Bank }\end{array}$ & SeABank & 3749 & 266 & 1994 \\
\hline 19 & Ocean Commercial Joint Stock & OJB & 3216 & 205 & 1993 \\
\hline
\end{tabular}




\begin{tabular}{|c|c|c|c|c|c|}
\hline No. & English Name & Abbreviation & $\begin{array}{l}\text { Total } \\
\text { Assets }\end{array}$ & $\begin{array}{c}\text { Total } \\
\text { Equity }\end{array}$ & $\begin{array}{c}\text { Year of } \\
\text { Establishm } \\
\text { ent }\end{array}$ \\
\hline & Bank & & & & \\
\hline 20 & $\begin{array}{l}\text { An Binh Commercial Joint Stock } \\
\text { Bank }\end{array}$ & ABBank & 3154 & 267 & 1993 \\
\hline 21 & $\begin{array}{l}\text { Tien Phong Commercial Joint } \\
\text { Stock Bank }\end{array}$ & TPBank & 2407 & 198 & 2008 \\
\hline 22 & Housing Bank of Mekong Delta & MHD & 2111 & 165 & 1997 \\
\hline 23 & $\begin{array}{l}\text { Orient Commercial Joint Stock } \\
\text { Bank }\end{array}$ & OCB & 1828 & 188 & 1996 \\
\hline 24 & $\begin{array}{l}\text { Nam A Commercial Joint Stock } \\
\text { Bank }\end{array}$ & NamABank & 1744 & 156 & 1992 \\
\hline 25 & $\begin{array}{l}\text { National Citizen Commercial Joint } \\
\text { Stock Bank }\end{array}$ & NCB & 1722 & 150 & 1995 \\
\hline 26 & $\begin{array}{l}\text { Viet A Commercial Joint Stock } \\
\text { Bank }\end{array}$ & VietABank & 1664 & 170 & 2003 \\
\hline 27 & $\begin{array}{l}\text { Viet Capital Commercial Joint } \\
\text { Stock Bank }\end{array}$ & VietCapitalBank & 1205 & 155 & 1992 \\
\hline 28 & $\begin{array}{l}\text { Petrolimex Group Commercial } \\
\text { Joint Stock Bank }\end{array}$ & PGBank & 1205 & 156 & 1993 \\
\hline 29 & $\begin{array}{l}\text { Kien Long Commercial Joint } \\
\text { Stock Bank }\end{array}$ & KienLongBank & 1080 & 157 & 1995 \\
\hline 30 & Saigon Bank for Industry \& Trade & SGB & 740 & 163 & 1987 \\
\hline 31 & $\begin{array}{l}\text { Mekong Development Joint Stock } \\
\text { Commercial Bank }\end{array}$ & MDB & 345 & 190 & 1992 \\
\hline
\end{tabular}

Source: Collected by author from finance. vietstock.vn

\section{Copyright Disclaimer}

Copyright for this article is retained by the author(s), with first publication rights granted to the journal.

This is an open-access article distributed under the terms and conditions of the Creative Commons Attribution license (http://creativecommons.org/licenses/by/3.0/). 